\title{
The Effects of Regional Governance, Education, and In-Migration on Business Performance
}

Abstract: National institutional settings are important to small business performance. However, national institutions take time to change. So, is there any way to boost firm performance in 'weak' institutional environments? This study aims to answer this question by examining the role of local institutions represented by the quality of local governance, instead of the very broad national constitutional configurations. Moreover, it is suggested that regional human capital, whether locally built-up (through local education) or externally imported (through in-migrants) is able to strengthen the positive impacts of local governance on small business performance. A test on more than 1.3 million firm-year observations of Vietnamese small businesses confirms the moderating effects of education and in-migration on the relationship between local governance and firm performance.

Keywords: Regional governance; Regional education; In-migration; Business Performance; Vietnam

\section{Introduction}

Institutions are an important determinant of entrepreneurship and business performance (Bruton et al., 2010). A large body of literature suggests that formal institutions that range from constitutional configurations (Carbonara et al., 2016) to property rights ( institutions, ranging from the norms of corruption (Gjalt et al., 2012) to the values of

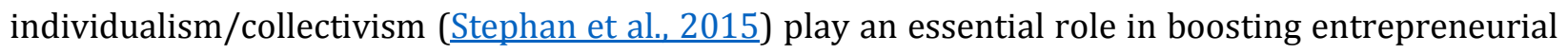
performance and growth. However, institutions are sticky and take time to change (Bolen \& Williamson, 2019), especially the informal institutional forces such as norms of doing business, values, and beliefs (Williamson, 2000). A question therefore arises: how to facilitate entrepreneurial activities and firm performance when there is limited room to adjust institutional settings?

This study aims to answer this question by making two adjustments to the model conventionally used to investigate the importance of institutions on firm performance.

First, we suggest a downgrade in the unit of analysis from the very broad general constitutional and legal configurations to local institutional environments. The institutional settings at the local level, represented in this study by the governance quality of local governments, may strongly influence the performance of local businesses. ${ }^{1}$ There are three reasons underpinning this expectation. The first is

\footnotetext{
${ }^{1}$ The institutional settings at the local level go far beyond the governance quality of local governments, and include local resource allocation and local market mechanisms, as specified in Williamson (2000) 'institutions of governance'. In this study, we focus on one aspect of local institutional settings, i.e., the governance quality
} 
that, within a relatively homogenous formal institutional setting (a country), the 'play' of the institutional game may vary across regions (Autio \& Fu, 2015; Du \& Mickiewicz, 2016). This is particularly the case in developing countries where the legal infrastructure is weak and incomplete; the onus is on local authorities to interpret central legislation and implement the regulations and they can do so to enrich themselves rather than to benefit society at large (Nguyen, 2018). The second reason is that firms in developing countries are typically small businesses; due to their age and size liabilities, they are generally restricted to trading within their local markets, which are strongly shaped by the governance quality of local governments rather than by the very broad national legal institutions (Zhou, 2014). The third reason is that local governance arrangements are easier to improve than national general institutions. The higher the level of institution, the more time it takes to change (Williamson, 2000).

Second, we suggest a set of factors that may be able to moderate the effects of local governance on firm performance. Given that institutions are human-made constraints on our behaviours and operate to reduce the uncertainties and transaction costs of doing business (orth, 1990), regions with higher levels of human capital may be able to strengthen the effects of local governance on firm performance. Human capital, at the regional level, is either locally built-up through education (Armen \& Quinton, 2012), or externally imported through migration (Powell et al., 2017). Thus, another question emerges: which is more important for strengthening the effects of local governance on firm performance: the quality of human capital (through improvements in local education systems) or the quantity/variety of human capital (through increasing the number of migrants)?

We answer these questions by examining a set of 1.3 million observations of Vietnamese private businesses from 2006 to 2016. We recognise that the relationship between entrepreneurship and local governance is simultaneous (endogenous) (Carbonara et al., 2016) and employ a set of instrumental variables to facilitate the IV-GMM estimation.

The regression results confirm that local governance quality is an important determinant of firm performance. Also, that both types of regional human capital, whether developed through education, or imported through in-migration, are statistically significant in enforcing the positive effects of local governance. As such, our study suggests that regions endowed with 'weak' (e.g., less effective)

of local governments because this significantly influences resource allocation and market mechanisms at the local level (Charron et al., 2014). 
governance arrangements may enhance the positive impacts of their local governance on firm performance by improving local education quality and welcoming migrants.

This study makes some important contributions to the entrepreneurship literature and the literature on migration economics. First, it goes beyond the conventional study of (national) institutions Carbonara et al. (2016) to suggest that local governance arrangements also matter. We argue that local institutions (represented in this study by the governance quality of local governments) may strongly shape the surrounding norms and practices of doing business as well as entrepreneurial incentives, which consequently influence local firm performance. Second, this study is the first to analyse the links between local governance, in-migration, and education and assess their simultaneous impacts on firm performance. It sheds light on the long-lasting debate as to whether locally built-up human capital (through education) or externally imported human capital (through migration) is more crucial to local firm performance (Borjas, 2014). Third, this study provides a potential mechanism through which education and in-migration may moderate (enhance) the effects of institutions on firm performance. Understanding this mechanism is important because it helps improve the effectiveness of local governance by focusing on managing some controllable factors, such as local education quality and in-migration rates.

\section{Literature Review and Hypothesis Development}

In this section, we investigate the potential influence of local governance, in-migration, and education on firm growth performance. Figure 1 illustrates the theoretical framework. In the following section, we examine each of these relationships in detail.

$<$ Figure 1 inserts here $>$

\subsection{Local Governance and Firm Growth Performance}

Institutions are widely recognised as an important determinant of business activity and performance (Aidis, 2005). In general, institutions are sets of human-made rules. These may be explicit and formal, such as national constitutions and legal regulations (North, 1990) or implicit and informal, such as social norms and professional practices (Williamson, 2000). The purpose of setting up these 'rules of the game' is to reduce transaction costs and facilitate shared values and beliefs within societies so as to maintain social structure and stability. From the economics viewpoint, institutions are a crucial factor in shaping entrepreneurial incentives (Bruton et al., 2010). For example, property rights are found to be highly associated with private firm investment decisions ( $\underline{\mathrm{Cull} \& \mathrm{Xu}, 2005}$ ) because in an 
insecure/weak institutional environment, entrepreneurs are more opportunistic and lack the motivation to pursue sustainable growth (Acemoglu \& Johnson, 2005).

The importance of the informal institutions is increasingly being appreciated. The role of values (such as individualism and socialism) and social norms (such as corruption and relationship-based transactions) have been found to significantly influence entrepreneurial perceptions and therefore firm performance (Aidis, 2005; Stephan et al., 2015). Unlike the formal institutional forces, informal institutions are not legally binding; however, their effects may even be stronger since entrepreneurs, in an endeavour to gain social acceptance of their activities, are keen to adopt and follow the pre-set rules as per social expectations (DiMaggio \& Powell, 1991).

It is evident that formal and informal institutions are extremely important but recent studies point out that a well-structured set of the 'rules of the game' may be ineffective if the rules are not 'played' properly at the local level (Du \& Mickiewicz, 2016). Hence, analysis that focuses on understanding how the rules are executed (at the local level) is at least as important as understanding what the rules are. This switch in analysis is highly related to the governance quality of local governments (Nguyen et al., 2018). In weak and underdeveloped institutional environments, local authorities have substantial room to play the institutional games (to interpret the central laws) 'off-road', i.e., to favour their private gains instead of social benefits (Nguyen et al., 2018). This leads to a situation in which a country with homogenous formal institutional settings may have inconsistent governance quality across regions (Aidis, 2005).

We acknowledge that the governance quality of local governments is but one facet of institutional settings at the local level. However, Williamson (2000) proposes the concept of institutions of governance to account for the importance of resource allocation and market mechanism in local institutional settings. Given that local governance settings strongly affect how local resources are allocated and to what extent the market mechanism is allowed to function (La Porta et al., 1999), we believe that local governance plays the primary role in establishing the local institutional settings that strongly affect local business growth performance. Therefore, we have:

Hypothesis H1: In a region, local institutional quality represented by the governance quality of local government is positively associated with local business revenue and profitability growth.

\subsection{Education and Firm Growth Performance}

One of the strongest drivers of business success is the quality of human capital that entrepreneurs have obtained through education (Kolstad \& Wiig, 2015). Human capital theory suggests that people 
with higher levels of human capital obtained through education are more productive. As such, from the governance perspective, it is crucial that local governments strive to improve the quality of local education, as doing so will boost local firm performance thereby generating higher tax revenues (Van Praag \& Van Stel, 2013). It is noteworthy that education is a built-up regional sociological factor in the sense that the skills and knowledge disseminated to local citizens are tightly controlled by local governments and strongly influenced by local informal institutional settings (values and norms) (Dheer, 2017). This type of human capital is sharply contrasted to the imported type of human capital (embedded in migrants), which will be discussed in the next section.

The importance of entrepreneurs' schooling on business performance has been widely investigated in the literature. Early models employ the pro-entrepreneurial human capital perspective to argue that education enhances individuals' entrepreneurial and managerial capabilities (Le, 1999; Lucas, 1978; Robinson \& Sexton, 1994). These skills are positively associated with their confidence in being able to successfully start new ventures, resulting in a higher business ownership rate in an economy. Societies with a more highly educated population can gradually nurture an entrepreneurial culture, in which the values and norms of doing businesses are built up to favour firm growth performance.

Another strand of literature argues that education not only increases entrepreneurial capital but also enhances the quality of human resources (Matlay \& Piperopoulos, 2012; Van Der Sluis et al., 2008). As a result, better-educated people are more likely to find employment opportunities in positions that are more secure and offer higher compensation and better career development prospects to utilise their human capital (Dheer, 2017). From this viewpoint, higher education may raise the skill sets and commitment of employees to their jobs rather than boosting entrepreneurial activities.

Through either (or both) mechanism(s), we expect that education will boost the quality of local employees and/or the quality of new ventures, leading to better business growth performance. ${ }^{2}$

In addition to these conventional models of human capital, Millán et al. (2014) offer an alternative model to examine the influence of education. In their framework, the education level of employees may shape the supply function, in the sense that the capability of well-educated employees means they can uplift the supply curve. Meanwhile, the education level of consumers may shape the demand function in that education boosts consumer preferences for variety and innovative products. This

\footnotetext{
2 Van Praag et al. (2013) argue that education is positively associated with both entrepreneurial and professional human capital. However, entrepreneurs have higher returns to formal education than employees, due to fewer organisational constraints. Entrepreneurs enjoy a higher degree of personal control over how to use their human capital compared to employees, leading to a more effective utilisation.
} 
offers entrepreneurs a chance to supply new, alternative, more differentiated, and innovative products to a higher educated market.

In general, education enhances the human capital of entrepreneurs and employees, leading to more efficient operations and improvements in firm performance. At the same time, education raises local demands for new and innovative products, bringing more opportunities to small businesses. Consequently, we propose that:

Hypothesis H2a: In a region, the size of local educated population is positively associated with local business revenue and profitability growth.

\subsection{In-migration and Firm Growth Performance}

While the human capital generated by education is locally built-up, the human capital associated with migrants is externally imported in the sense that local authorities are unable to control the types of skills and knowledge that in-migrants introduce to their new region (Jensen, 2014). While the importance of immigrants (i.e., those who make their home in another country) has been widely investigated, the role of in-migrants at the sub-national level is largely unexplored (Levie, 2007). Compared to immigration, the movements of in-migrants are far less restricted and are therefore more difficult for local authorities to control (Jensen, 2014). However, this type of within-country human resource movement may exert substantial influence on local business performance.

The most cited mechanism explaining migration is the human capital model, in which migrants move because they perceive that the employment opportunities and economic income benefits of moving are greater to those offered by staying. There are two theories that follow on from this argument: the theory of skilled workers (Zelekha, 2013) and the theory of disadvantaged workers (Light, 1979). The former relates to the inflow of skilled migrants that may increase the number of high-quality human resources. The imported knowledge and skills from these migrants may be quite different from those of the native worker. This diversity of know-how may facilitate innovation and boost productivity, leading to better performance for local firms (Peroni et al., 2016).

The theory of disadvantaged workers holds the view that migrants may be discriminated against in the local labour market because they are outsiders, or it may be that their unrecognised qualifications and experience or their lack of knowledge of the local market simply renders them uncompetitive. Migrants are therefore pushed into an entrepreneurship career because they have no other choices. To survive the competition in the new market, migrants are forced to find new ways of combining 
resources or using new resources (e.g., social networks linked to the regions of origin) to provide innovative and distinguished products (Lamine et al., 2015; Levie, 2007).

In short, from the human resource perspective, whether such individuals are viewed as skilled migrants or as displaced entrepreneurs, they will contribute to the growth performance of local businesses.

Besides the human resource theory, the institutional theory also offers a set of explanations for the migration-firm performance relationship. First, migrants, having come from elsewhere and being equipped with a set of distinct values, beliefs, norms, and practices, may be able to identify patterns in events that appear uncorrelated to life-long residents, and organise them into business opportunities/novel solutions (Levie, 2007). Second, by deciding to relocate to a new home, migrants may be less risk-averse than the life-long residents (Zelekha, 2013). Finally, the theory of migration enclaves suggests that a high migration rate benefits local firm performance due to high intramigration-group solidarity with shared values, norms, and trust that facilitate economic activities (Peroni et al., 2016).

Besides these direct effects, Jensen (2014) also offers an indirect mechanism of migration, in which there might be an opportunity to exploit the knowledge spill-overs from migrants to natives. The magnitude of this spill-over effect depends on the nature and the range of networks that migrants may have, as well as on the level of absorbability that the native is able and willing to exercise.

In general, even though local authorities usually find it hard to control the types of human capital associated with in-migrants, the market mechanism (competition) will ensure that migrants contribute to local business either as innovative entrepreneurs with unique economic initiatives or as high-performing employees. Therefore, we have:

Hypothesis H2b: In a region, the size of local in-migrated population is positively associated with local business revenue and profitability growth.

\subsection{The Moderating Effects of Education and In-migration}

\subsubsection{Education}

Education enlarges the citizens' capacity to acquire and process the information necessary to arrive at an accurate assessment of the functioning of political institutions. Armen and Quinton (2012) call this effect the accuracy-inducing function of education. The better educated are more interested in the operations of governments than the less educated; they are also more inclined to actively obtain 


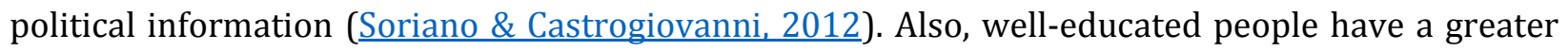
tendency to participate in political activities and are more eager to improve the weaknesses in their home political systems. Further, the educated are more likely to correctly identify and address the issues necessary to improving the governance quality of local governments (Iversen et al., 2016). For this reason, the educated are more responsive to a change in local governance quality and are more likely to be successful in transforming these institutional improvements into their business performance (if they are entrepreneurs) or their organisation performance (if they are employees).

Besides the accuracy-inducing function, education also has a norm-inducing function. This function of education, according to Armen and Quinton (2012), is the change of values and beliefs held by the educated on the roles of governments. Educated individuals are more demanding regarding the quality of public services than are the less educated. They are also more likely to raise critical questions concerning the functions and effectiveness of local authorities in dealing with social and political affairs. By following a set of values and beliefs that are more politically-engaged than the less educated, well-educated people are more likely to be involved in local institutional settings and adjustments (Jetter \& Parmeter, 2018). As a result, the educated are more capable of assimilating institutional improvements, which may turn into a competitive advantage and boost local business performance.

Finally, education also has a monitoring function on local authorities (Eicher et al., 2009). Educated people are equipped with better tools (knowledge and skills) to monitor the operations of politicians and public servants. Indeed, when there is little education, corrupt behaviour is likely to go undetected (Tonoyan et al., 2010). From this perspective, an educated populace plays the role of watchdogs as well as being recipients of local governance quality. By closely monitoring the local governance systems, the educated may have a better chance (compared to their less-educated counterparts) of leveraging improvements in local governance quality.

In general, entrepreneurs doing business in regions that have a larger population of educated individuals may, thanks to the effects of the accuracy-inducing, norm-inducing, and monitoring functions of education, achieve higher performance than those who are doing business in regions with a smaller population of educated individuals. As such, we have:

Hypothesis H3a: The effect of local governance quality on local business revenue and profitability growth is stronger in regions having a larger population of educated individuals.

\subsubsection{In-migration}


Unfortunately, the literature examining the influence of migration on local institutions lacks a consistent theory because empirical findings appear to disprove theoretical arguments. Borjas (2014), in his recent book, states the institutional problem of immigration:

'[...] net gain to world GDP could be substantial if people could move freely across country as long as the institutional and economic infrastructure that gives the developed world its productive edge remains intact after the inflow of perhaps billions of new workers.'

In his relatively depressing view of immigration, Borjas asserts that institutions developed to facilitate productivity and growth in industrialised countries may be harmed by immigrants. Even though Borjas does not precisely define which institutions - economic, political, legal, or informal he thinks immigrants may harm, he posits that the negative effect of immigration may exist in the short and as well as the long terms. Borjas's fear of 'bad' institutions being imported by immigrants, however, has received criticism from other scholars. Card and Peri (2016), for example, state that 'in almost every chapter the book maintains a uniformly dismal view about immigration'. By criticising the subjectiveness in Borjas's simulation settings and selective evidence presentations, they conclude that his view only 'presents half the story about the economics of immigration'.

Collier (2015) also shares a negative view of immigration. His key argument is that migrants do not only import human capital but also, and more importantly, the institutions and cultural characteristics that are responsible for their poverty. He postulates that the norms brought by migrants may be more opportunistic compared to the norms employed by the native. As such, migration may reduce the levels of general trust (trust in strangers) and pose a threat to the social model in the destination (Efendic et al., 2015).

However, empirical studies seem to paint another picture of migration. Immigrants are found to be positively associated with total factor productivity, long-run per-capita income, labour efficiency, higher living standards, and the destination's economic growth (Clark et al., 2015; Clemens \& Pritchett, 2016; Padilla \& Cachanosky, 2018). In the context of in-migration in this study, the effects of in-migrants on regional institutions may be weaker than the effects of immigrants on national institutions. However, we expect that in-migrants, no matter where they come from, contribute to rather than deteriorate the governance quality of local governments, for the following reasons.

First, people who leave their original regions due to the bad quality of institutions are unlikely to want to recreate them in their new homes (Baudassé et al., 2018). Rather, migrants are keen to learn and adopt the new set of local institutions in an endeavour to legitimise their citizen status. Based on 
this argument, Cheong et al. (2007) posit that the view of the native that local social capital may be under the threat of destruction by immigration is, in principle, the fear of multiculturalism. In contrast to this conservative viewpoint, it has been evidently shown that migrants do not only stimulate entrepreneurship at their new home but also positively contribute to the local governance systems (Eicher et al., 2009).

Second, displaced entrepreneurs (migrants with unrecognised qualifications and experience) may contribute to local governance quality by pushing authorities to be more inclusive. This leads to efficiencies in the sense that authorities become more creative and clever in implementing policies and in designing their own initiatives for the migration sector's development (Poprawe, 2015). Also, skilled migrants may boost governance quality in that they help monitor and criticise the weaknesses of the governance settings using their fresh eyes and knowledge. As such, migrants, whether they be displaced entrepreneurs or skilled workers, are shown to have an essential positive influence on local governance quality.

Third, people living in regions with more historical migration are found to be more innovative, tolerant to ethnic diversity, less risk-averse, and care more about other social minority groups (Padilla \& Cachanosky, 2018). These values contribute to the formation of an inclusive and proactive governance system. This favourable institutional environment is apparently an incubator for ambitious entrepreneurs (Sequeira et al., 2017). ${ }^{3}$

In general, regions that have a larger population of migrants may nurture ambitious entrepreneurs and high-skilled employees, who are able to contribute significantly to local governance quality, which positively influence local business performance. Therefore, we have:

Hypothesis H3b: The effect of local governance quality on local business revenue and profitability growth is stronger in regions having a higher rate of in-migration.

\section{Data and Methodology}

\subsection{Data}

The empirical context of this study is Vietnam. The country has a wide range of local governance quality and a large number of labour movements across regions (Nguyen et al., 2018; Nguyen et al..,

\footnotetext{
${ }^{3}$ For the sake of completeness, it is noteworthy that migrants not only contribute to the institutional improvements of their new home, but also have a positive impact on the institutional quality of their origin. See Hirschman (2007) 'exit and voice' model.
} 
2015) that fit well into the theoretical settings of this study. To test the proposed hypotheses, we employ the Annual Enterprise Survey dataset provided by the Vietnam General Statistics Office (GSO). The survey was first conducted in 2000, and the dataset has been updated annually. By regulation, all businesses having more than 10 employees are required to participate in the survey. For businesses with fewer than 10 employees, a sample is randomly selected to participate in the survey. The dataset provides comprehensive information about firm financial characteristics, employment, investment, and performance. The scope of the survey comprises both manufacturing and service industries and includes all types of ownership. The panel data obtained from GSO is 17 years, from 2000 to 2016.

However, the period of analysis in this study is scaled down to 11 years, from 2006 to 2016 to match with the second dataset: Provincial Competitiveness Index (CPI), a joint product of the Vietnam Chamber of Commerce (VCCI) and the US Agency for International Development (USAID). This dataset is a panel of provincial governance quality. The quality is scored from 0 to 100 , the higher the score, the better the governance quality. The PCI index is calculated based on a survey of more than 17,000 domestic firms and 1,700 foreign firms across provinces in Vietnam. The pilot study was conducted in 2005 on one-third of the total provinces of Vietnam. In 2006, the PCI index became available for all provinces and has been updated annually.

We combine the firm-level GSO dataset with the provincial level PCI dataset to create a multi-level panel of 11 years. While the PCI panel is strongly balanced, the GSO dataset is unbalanced and requires cleaning before using. Specifically, we drop all observations that have meaningless accounting reports. We control the outliers by censoring the top and bottom $1 \%$ of observations in each variable.

Our population of interest in this study is private businesses of every size: micro-firms, small and medium-sized enterprises (SMEs), and large corporations. It is noteworthy that Vietnam is an entrepreneurial economy. The number of private micro-firms and SMEs accounts for $97.7 \%$ of the total private business population, with an average firm age of 6 years and an average number of employees of 20. These statistics reveal that Vietnamese private firms are very small and young; as such, they may be highly sensitive to their surrounding institutional environments. ${ }^{4}$ In this study, we exclude state-owned firms because their operation may not follow market principles (Zhou, 2017).

\footnotetext{
${ }^{4}$ One may argue that large firms are not bounded to any particular local market but rather operate nationwide (Nguyen et al., 2018). As such, they are less sensitive to local governance arrangements. We take into account this argument by also analysing the large firms excluded from the dataset. The findings remain robust to the proposed hypotheses and the results are available upon request.
} 
Nor do we count foreign-owned firms since they enjoy special treatment from central government, which may distort their sensitivity to local governance quality (Nguyen \& Dijk, 2012). The final sample in our study thus includes $1,366,533$ observations of domestic private businesses. ${ }^{5}$

\subsection{Variables and Summary Statistics}

The dependent variable of interest is firm performance. For the sake of robustness, we measure firm performance using two variables: revenue growth and profit growth. Revenue is a proxy for firm market-based performance relative to its peers in the same industry. Firms with higher market shares enjoy several competitive advantages, such as better brand recognition, higher brand values, more business opportunities, and stronger market powers (Diewert \& Nakamura, 2007). Profitability, on the other hand, is a productivity-based performance measure. It represents the relationship between inputs (operation cost) and outputs (revenue). Firms with higher profits ceteris paribus have a more efficient cost function, which could result from better production technology or stronger managerial capital (Diewert \& Nakamura, 2007).

We expect that both types of performance are a function of local governance quality. We use profit and revenue growth rather than simple levels of performance to enhance the robustness of our measures. Growth variables reduce the impacts of firm initial characteristics and year-specific socioeconomic fluctuations on firm performance (Nguyen et al., 2018). As such, Revenue growth is the percentage change of revenue of a firm between two consecutive years. Similarly, Profit growth is the percentage change of profitability of a firm between two consecutive years.

To measure the governance quality of local governments, we use the PCI index. This index is a combination of nine sub-indices, each evaluating a dimension of local government such as controls for corruption, levels of transparency in public services, and the leadership proactivity of local authorities. Details of the nine sub-indices are presented in Appendix 1. The PCI score ranges from 0 to 100; the higher the score, the better the quality of local government. In the study period, the average PCI score is 60 . However, a province may get as low as 36 , while another may achieve as high

\footnotetext{
${ }^{5}$ According to the Vietnam Enterprise Law, there are four types of firm size. Micro-enterprises are firms operating with fewer than 10 employees. Small enterprises are firms with 10 to 200 employees and total registered capital of less than 20 billion VND (approximately 1 million USD). Medium enterprises are firms that have 200-300 employees and total registered capital of less than 100 billion VND (approximately 5 million USD). And large enterprises are firms operating with more than 300 employees and 100 billion VND registered capital. Capital is the first criterion in categorisation.
} 
as 77. These statistics show that there is substantial heterogeneity in the quality of governance of local governments across provinces in Vietnam.

We measure the levels of locally built-up human capital using the High-graduates variable, which is the ratio of high-school graduates over the total local population. The higher the ratio, the higher the presence of educated people in a local population. To capture the imported human capital, we use the In-migrants variable, which is the net percentage of in-migrants over the local population (less the number of emigrants).

Following the extant literature, we include a set of covariates that may influence firm performance. At the firm-level, we control for firm size, firm age, and industry. These variables represent firmspecific and industry-specific characteristics that significantly determine firm growth (Valliere \& Peterson, 2009; Zhou, 2017). At the entrepreneur-level, we control for owner age, gender, and education. These individual-specific factors play an essential role in determining firm performance because they indicate the knowledge and experience associated with the entrepreneurs, which may markedly influence their ability to recognise and evaluate business opportunities (Tran \& Santarelli, 2014). At the provincial level, we include the following variables: population density and consumption value per capita, which control for local market demands (guyen et al., 2018); the ratio of working population to total population to control for local labour supply; and the foreign direct investment (FDI) per capita value to control for local market development as well as the competition among provinces in attracting capital and investments. We also control for time-invariant provincial characteristics using a set of dummy variables. The definition and summary statistics of these variables are presented in Table 1. The pairwise correlation matrix is presented in Appendix 2.

$<$ Table 1 insert here>

\subsection{Specifications and Estimation}

Based on the conventional firm performance models (Du \& Mickiewicz, 2016; Nguyen et al., 2018), we propose the following expanded reduced-form equation. This is our baseline specification:

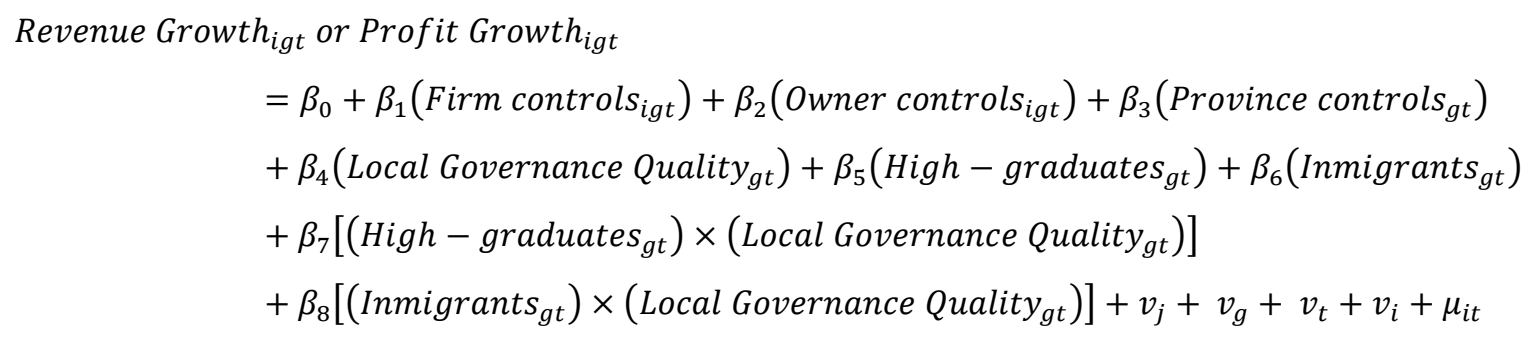


where $i$ denotes an individual firm, $g$ is the province, and $t$ a year. Therefore, Revenue Growth Ggt $_{\text {or Profit Growth }}$ igt is the revenue or profit growth rate that firm $i$ in province $g$ achieves in year $t$. The term (Firm controls igt ) is comprised of the variables firm age, labour size, and the squared term of firm age to control for the potential non-linear effects of firm age on firm growth; ${ }^{6}$ the term (Owner controls ${ }_{\text {igt }}$ ) includes owner age, owner gender, and owner education variables; (Province controls ${ }_{g t}$ ) constitutes the variables consumption value per-capita, local population density, the workforce, and FDI per-capita. The term (Local Governance Quality igt $_{\text {) }}$ is

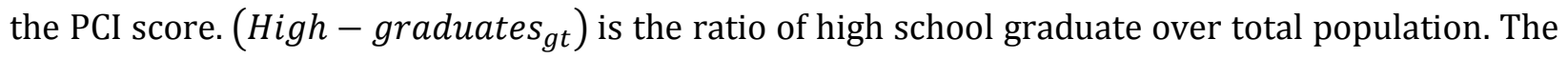
term (Inmigrants It ) is the ratio of the number of in-migrants over the population. As such, the interaction terms $\left(\right.$ High - graduates $\left.g_{g t}\right) \times\left(\right.$ Local Governance Quality $\left._{g t}\right)$ and $\left(\right.$ Inmigrants $\left._{g t}\right) \times$

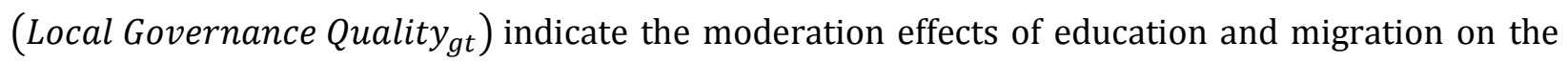
relationship between local governance quality and firm growth.

In addition, the equation includes an industry-specific component $v_{j}$, a time-specific component $v_{t}$, and time-invariant provincial characteristics $v_{g}$, which are controlled by corresponding dummies. The term $v_{i}$ represents all time-invariant, firm-specific factors that may influence firm performance. Finally, $\mu_{i t}$ is the idiosyncratic error.

It is noteworthy that while local governance affects small business performance, the effect may also be reversed: entrepreneurship development may influence the quality of local governance. Specifically, regions that enjoy an effective system of governance may have a higher level of entrepreneurial performance, and vice versa (Wennberg et al., 2013). More importantly, when a region is characterised by high-level entrepreneurial capital, it is more likely to develop institutions that favour entrepreneurship. Because governance quality is determined endogenously, perhaps influenced by the level of entrepreneurship (Carbonara et al., 2016), our model may encounter potential endogeneity issues.

To address this endogeneity problem, we propose the use of the IV-GMM technique. The key issue with identifying potential instruments was finding external variables that are correlated with the endogenous local governance variable, but are uncorrelated with firm performance. Following Nguyen et al. (2018) we suggest the following set of variables that meet these requirements.

\footnotetext{
${ }^{6}$ The regression results without the squared term of firm age remain robust and support the proposed hypotheses.
} 
The first instrumental variable is the length of period a provincial leader holds office. In Vietnam, provincial leaders are appointed by central government. As such, this variable is unlikely to be correlated with local business performance. At the same time, it is expected that the governance quality of a province in a particular period is significantly contingent on the leader's characteristics and period in office. Malesky et al. (2015) suggest that governance styles strongly influence the norms and practices of doing business. A 'good' authority with responsible leadership may facilitate pro-entrepreneurship policies and encourage productive entrepreneurial behaviours. A 'bad' authority with opportunistic leadership may give rise to rent-seeking behaviours and reduce the level of institutional trust (trust in government) (Hakhverdian \& Mayne, 2012). Given that leaders' characteristics may strongly influence local governance arrangements, we use the tenure period (period in office) in this study as a proxy for the governance styles of the leaders. Period in office is measured by the number of months (average for a given year) that the top provincial leader is in his/her position. It is noteworthy that although the leader appointed by central government has a five year period of tenure, local people (including local businesses) have the option to appeal against 'bad' leaders, leading to a change in leadership before the end of the fifth year. As such, it could be seen that a long period in office is correlated with 'strong' (i.e., effective) local governance. Therefore, we expect a positive relationship between a leader's tenure period and the local governance quality.

The second instrumental variable is changes in leadership. To measure the changes of leader, we employ leader switch events. Because power is highly concentrated at the leader's disposal, and each leader may have idiosyncratic knowledge of local administration and a different management style, the switching of leaders in a province may initially wield significant influence on the quality of governance. Nguyen et al. (2018) suggest that leader switch events may create a shock to the local business community in the sense that local policies and local governance arrangements may be altered, or even replaced by a set of completely new policies and arrangements, some of which may be contradictory to the previous ones. These changes may lead to institutional conflicts in which agents (e.g., local businesses) fail to comply with both sets of values at the same time (Ahlstrom \& Bruton, 2010). To adapt to the new governance system, firms need to adjust their management, behaviour, and expectation. These adjustments are institutional costs (James \& McGuire, 2016). The net benefits obtained from a leader switch event is likely to be positive if the adjustment costs are lower than the benefits. In saying this, it is noteworthy that changes in leadership may impose either positive or negative effects on local governance quality, depending on the new leaders' capacity and style. As such we hold a neutral expectation on the relationship between leader switch events and 
local governance quality. The Leader switch variable is a dummy that takes the value of 1 if there is a change of provincial leader in a year, and 0 otherwise.

Finally, this study also uses variables that capture the specific time points in tenure years that can make governance quality more likely to fluctuate. The Third-year dummy takes the value of 1 if a leader is in the third year of his tenure, and 0 otherwise. According to the data, in practice leaders are most likely to be changed every three years. Therefore, it is expected that in the third year of tenure, anticipating demotion, leaders may have more incentive to be corrupt and to become less proactive since they will not need to take responsibility for the consequences of their decision-making once they have left their positions. This adverse effect of the tenure appointment structure is briefly discussed in Tran (2018) using a similar instrumental approach. The fifth year may have a similar effect - it is the last year in the five-year official tenure period of appointment by central government. It is expected that the negative effect of the fifth year is even stronger than the effect of the third year because leaders know that it is more likely that they will be re-assigned to new positions than if they had remained in post for only three years. This five-year tenure system, as such, may give rise to rent-seeking incentives approaching the end of the period. The Fifth-year dummy takes value 1 if a leader is in the fifth year of his tenure, and 0 otherwise.

An over-identification test is employed to investigate whether the external variables are truly exogenous. The Hansen (J) tests confirm the validity of the suggested IVs. Also, the VIF tests suggest there is no significant multicollinearity in our specifications.

\section{Results}

\subsection{Empirical Results}

The regression results are reported in Table 2. Columns 1 to 3 are for revenue growth, and columns 4-6 are for profit growth. The specification tests indicate no serious issues with the model settings. The Sanderson-Windmeijer (SW) first-stage F statistics and the Hansen (J) statistics show that the instrumental variables are valid and reliable.

$<$ Table 2 insert here>

The coefficients associated with local governance quality are positive and statistically significant in all specifications, indicating that the surrounding local governance arrangements are an important determinant of private businesses' growth performance. As such, hypothesis H1 is fully supported. In column (1), the result indicates that when local governance quality (the PCI score) increases by 1 point, firm revenue growth will improve by $4 \%$, holding all else constant. 
The coefficients associated with the education variable (high school graduates) and the ratio of inmigrants in local population variable are positive and statistically significant in most specifications (with an exception in column 4). This finding indicates that regional human capital, whether locally developed or externally imported, is an essential determinant of private businesses' growth performance. Therefore, hypotheses $\mathrm{H} 2 \mathrm{a}$ and $\mathrm{H} 2 \mathrm{~b}$ are supported to some extent. This finding is consistent with the argument of Van Praag et al. (2013), in which the variety of skills and knowledge are asserted to be as crucial to productivity as the quality of knowledge. Indeed, in some cases, a variety of skills among employees is even more important than high-quality but homogenous skills. However, in the context of this study, we have not yet been able to identify which effect is stronger since the economic size of the in-migration effect is not consistently larger than the economic size of the local education effect.

Regarding the interaction terms between local governance and education/in-migration, the regression coefficients are positive and statistically significant in most specifications (with an exception in column 5). This finding provides some initial evidence showing that the effect of local governance on firm growth performance may be moderated by regional human capital. Specifically, firms operating in regions with a higher level of educated population, or a higher ratio of in-migrants, are more responsive to the positive effects of local governance. In other words, the effects of local governance on private business (especially on their revenue growth) are stronger in regions with a more educated or migrated population. This finding partially confirms the validity of hypotheses H3a and H3b. It is noteworthy that the result in column (5) has not been able to confirm the moderating effect of in-migration on the relationship between local governance and profit growth.

To analyse the moderation effects in more detail, Figure 2 presents the predictive margins of firm revenue growth using different values of education and in-migration. The predictive margins of profit growth are similar and available upon request. The figure shows that the marginal effects of inmigration are slightly stronger than the marginal effects of education. Moreover, provinces with one standard deviation above the mean of regional human capital, whether this be due to a better education quality or a higher in-migration rate, appear to have stronger positive governance effects on local firm revenue growth.

\section{$<$ Figure 2 insert here $>$}

In terms of the control variables, their effects seem to be more statistically significant in the revenue growth specifications than in the profit growth specifications. In general, firm age has a non-linear effect on revenue growth such that as firms age their revenue growth rate reduces; however, once a 
particular threshold of firm age has been reached, their revenue growth will reverse and increase. Higher owner age has a consistently negative effect on firm revenue and profit growth. Meanwhile, female-run businesses appear to earn more revenues and profits than their male-run counterparts. Finally, at the provincial level, population density hurts revenue growth, but having a higher proportion of the population in the workforce has a positive impact.

\subsection{Robustness Tests}

\subsubsection{Sub-components of Local Governance}

This section explores the effects of PCI sub-indices. The nine dimensions of local governance are measured as follows:

Entry costs, which is a measure of the length of business registration in days, the number of licenses and permits necessary to start operations, and the percentage of firms that need additional licenses/permits; Land access, which is a measure combining two dimensions of the land problems confronting entrepreneurs: how easy it is to access land and the security of tenure once land is acquired; Time costs, which is a measure of how much time firms waste on bureaucratic compliance, as well as how often and for how long firms must shut down their operations for inspections by local regulatory agencies; Business support, a measure of provincial regulations and services for private sector trade promotion, provision of regulatory information to firms, business partner matchmaking, provision of industrial zones or industrial clusters, and technological services for firms; and Labour and training, which is a measure of the regulations promulgated by provincial authorities to promote vocational training and skills development for local industries and to assist in the placement of local labour.

In addition, there are also indices capturing the quality of governance such as: Transparency, which is a measure of whether firms have access to the proper planning and legal documents necessary to run their businesses, whether those documents are equitably available, and whether new policies and laws are communicated to firms and predictably implemented; Corruption controls (informal charges), which is a measure of how much firms pay in informal charges, how much of an obstacle those extra fees pose for their business operations, and whether payment of those extra fees garners the expected results or 'services'; Leadership proactivity, a measure of the creativity and cleverness of provinces in implementing central policy, designing their own initiatives for private sector development, and working within sometimes unclear national regulatory frameworks to assist and interpret them in favour of local private firms; and Legal institutions, a measure of the private sector's confidence in provincial legal institutions; whether firms regard provincial legal institutions as an 
effective vehicle for dispute resolution, or if they constitute a viable avenue for appealing against corrupt official behaviour.

The regression results are reported in Appendix 3a and Appendix 3b. In general, entry costs, land access, transparency, labour and training, and legal institutions have positive effects on firm revenue and profit growth performance.

Meanwhile, improvements in corruption controls and leadership proactivity seem to exert negative effects on firm growth performance. This finding may initially appear counter-intuitive. However, when zooming into the behaviour of corrupt officials via the lens of institutional theory, we notice that officials, especially those who benefit from the institutionalised norms of corruption, are strongly against change and tend to revert to the 'old rules'. Fritsch and Wyrwich (2014) suggest that local informal institutions are rather sticky, persistent, and deeply embedded in the way local business operates, even when the formal institutional frameworks completely change. As such, when the national leaders are proactive and introduce corruption controls as the new 'rules of the game', lower-level government officials may pay lip service to the new game without actually improving their services (De Jong et al., 2012). In many cases, the quality of services may even become worse, thereby adversely affecting the local business community (Nguyen, 2019).

We also notice that business support has no statistically significant influence on firm performance. The reason could be that the support activities provided by local government may not meet the actual needs of local businesses. Finally, time costs are positively associated with revenue growth while being negatively associated with profit growth. This finding reveals that some governance dimensions may exert non-monotone effects on firm performance.

\subsubsection{Small versus Large Businesses}

This section explores the contingent effects of local governance on small versus large firms. It is expected that small businesses, due to their age and size liabilities, operate mostly within their local markets; as such, they are more sensitive to local governance arrangements. Meanwhile, large firms are not bounded to any particular local market but rather operate nationwide. Therefore, they may leverage out and become less sensitive to local governance arrangements.

To test this possibility, we create three mutually exclusive dummies: micro-firms, SMEs, and large firms. These are defined in accordance with Vietnam Enterprise Law (see footnote 5 for details of the criteria). We then examine the interaction terms of these dummies with the governance variable to explore the potential contingent effects. 
The regression results are presented in Appendix 4, column (1) to (4). The group of micro-firms is set as the benchmark. The economic size of the coefficients associated with SMEs and large firms are positive and statistically significant, indicating that SMEs and large firms, on average, earn more revenues and profits than micro-firms. Also, the interaction terms between local governance and the two firm size dummies are negative. This is an indication that larger firms are less sensitive to local governance compared to smaller firms.

\subsubsection{Triple Moderation}

This section explores the triple interaction effects among education, in-migration, and local

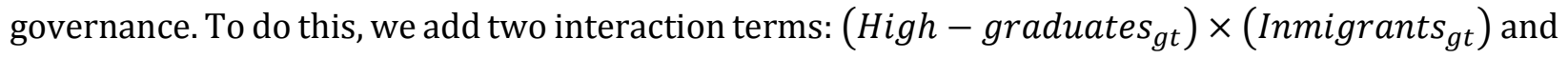
$\left(\right.$ High $\left._{- \text {graduates }_{g t}}\right) \times\left(\right.$ Inmigrants $\left._{g t}\right) \times\left(\right.$ Local Governance Quality $\left._{g t}\right)$ into equation (1).

The regression results are presented in columns (5) and (6) of Appendix 4. The coefficient associated with the interaction term of education and in-migration is positive and statistically significant in the revenue specification. This finding indicates that the two types of regional human capital are mutually enhancing. Also, the triple interaction term shows a positive effect on firm revenue growth. This finding could be interpreted as the joint effect of regional human capital (either locally built-up or externally imported) on the relationship between local governance and firm performance. This finding thus adds to the main findings in the sense that it evidently shows that the two types of regional human capital are not mutually exclusive but rather complement each other. It is noteworthy, however, that the triple interaction effect has no statistical meaning in the profit specification.

\subsubsection{Omitted-variable bias adjustment}

We acknowledge that the regression results presented in previous sections may suffer from omittedvariable biases. Therefore in this section, we employ the method proposed by (ㅅster, 2019), derived from the work of Altonji et al. (2005) to calculate a set of consistent estimates of the bias-adjusted treatment effects. This method is based on two assumptions: (1) a value for the relative degree of selection on observed and unobserved variables $\delta$ (which is normally assumed to be equal selection, i.e., $\delta=1$ ); and a value for $\mathrm{R}_{\max }$ - R-squared obtained from a hypothetical regression of the outcome on treatment and both observed and unobserved controls. ${ }^{7}$ Using these two inputs, an approximation

\footnotetext{
${ }^{7}$ If the outcome can be fully explained by the treatment and full control sets, then Rmax $=1$. However, in many empirical settings, due to measurement errors for example, the outcome cannot be fully explained even if the full control set is included.
} 
of the bias-adjusted treatment effect could be estimated by examining the ratio of the movement in regression coefficients in relation to the ratio of the movement in R-squared.

The three regional effects: local governance quality, in-migration, and education will be explored. Appendix 5 presents the estimation results. Column (1) shows the regression coefficients without controls (baseline effect); column (2) shows the regression coefficients with observable controls (controlled effect). Column (3) presents the bias-adjusted treatment effect with assumptions that $\delta=1$, and $R_{\max }=\tilde{R}+(\tilde{R}-\dot{R})$, in which $\tilde{R}$ is R-squared obtained from the controlled specification and $\dot{R}$ is the R-squared obtained from the baseline specification (Bellows \& Miguel, 2009). Column (4) presents the bias-adjusted treatment effect with assumptions $\delta=1$, and $R_{\max }=1.3 \tilde{R}$. ${ }^{8}$ Column (5) presents the value of $\delta$ for which the treatment effect becomes zero under the assumption that $R_{\max }=1.3 \tilde{R}$. To facilitate the calculation of the non-biased treatment effects, we estimate the coefficients in column (1) and (2) using fixed effects.

The results show that the coefficients estimated using the fixed effects (column 2) are all positive. However, the bias-adjusted treatment effect of in-migration in the revenue specification is negative under two different assumptions of $\mathrm{R}_{\max }$. Also, the values of $\delta$ for which in-migration and education have no effects on revenue growth are smaller than 1 . This is a signal that the distribution of the biasadjusted treatment effect of the two variables includes value zero. As such, we exercise substantial prudence when interpreting the causal effects of in-migration and education on revenue growth.

\subsubsection{Additional controls}

Given that our findings may suffer from unobservable biases and that time-invariant controls (e.g., the provincial dummies) may not completely address the issues, we propose in this section a method to control for time-variant provincial characteristics. Carpenter and Petersen (2002) and Guariglia (2008) set up the interaction terms between industry dummies and year dummies to control for unobservable time-variant factors at the industry level (e.g., changes in technology). We employ this method with a slight modification in which year dummies interact with provincial dummies. These interaction terms could account for time-variant socioeconomic changes at the provincial level. They also represent competition among the provinces in the sense that they capture the dynamics of provincial development.

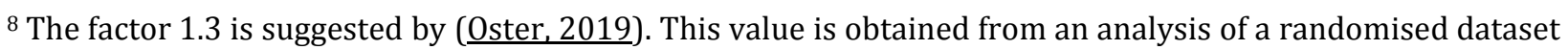
of 65 articles. This value was selected because it allows $90 \%$ of the results published in previous studies (lab or field experiments) to survive the omitted-variable tests.
} 
The regression results are reported in Appendix 6 and support our key arguments that regional education and in-migration could enhance the positive effects of local governance on firm performance. However, the coefficient associated with the interaction term between local governance and education in the profit specification (column 5) is not statistically significant; as such, it should be interpreted with care.

\subsubsection{Alternative measures of education and migration}

We double-check the robustness of our findings using a different set of variables to measure the levels of built-up and imported human capital. Specifically, instead of using the number of high school graduates to indicate the level of education, we additionally employ other measures to capture the locally built-up human capital, such as the number of university teachers and students, and the number of high-school teachers and students. These variables indicate the propensity to learning in the local context.

Further, for imported human capital, we also use the gross number of in-migrants (i.e. without deducting the number of emigrants) rather than the number of net in-migrants (where the number of emigrants is deducted). Our key arguments are robust to these changes for which the regression results are available upon request.

\section{Discussion and Conclusion}

This study examines the influence of local governance quality and the characteristics of regional human capital on small business performance. The empirical setting of this study is Vietnam, a developing country with substantial heterogeneity in its local governance arrangements and a large degree of labour movement across its regions (Dana, 1994; Venard, 1998). Employing a large and representative dataset, this study tests a set of hypotheses on the importance of local governance quality, local education, and the presence of in-migrants on small business performance. Through these investigations, this study makes the following three important contributions to the extant literature.

First, going beyond the study of Carbonara et al. (2016), which posits that the de jure constitutional configurations are an important determinant of small business performance, this study suggests that local governance arrangements also matter. Even though national institutional settings are the foundation of local governance, the impacts of general institutions on local firms are arguably less significant than are the local surrounding norms and practices of doing business (Du \& Mickiewicz,

2016). Therefore, rather than focusing on the very broad general institutions, it would be more 
appropriate to switch the unit of analysis to the surrounding institutional settings, including local governance quality (Nguyen et al., 2018; Peng, 2002). Also, the study of local governance is more relevant to private businesses in developing countries because these companies are relatively young and small, and so their operations are typically carried out within local markets, which are strongly shaped by local authorities.

Second, this study contributes to a long-lasting debate that aims to clarify whether locally built-up human capital (through education) or externally imported human capital (through migration) is

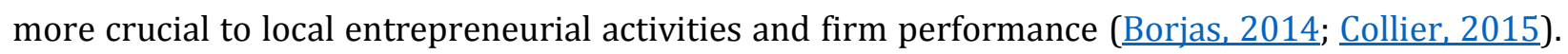
Our findings confirm the importance of both sources of human capital. While improving local education may enhance the size of local human capital (in that it creates a more educated population), it does not enrich the types of skills and knowledge of life-long residents. Migration, in contrast, brings in new skills and knowledge associated with the migrants, who come from other regions and are therefore endowed with different backgrounds, experiences, values, and beliefs (Baudassé et al., 2018). The empirical findings reveal that the variety of human capital gained from migration is as important to small firm performance as the skills obtained from education. As such, this study tells 'the other half' of Borjas's migration story by showing that migration may have some positive effects on the local business community.

Third, this study provides a potential mechanism through which education and migration may moderate the effects of institutions on firm performance. Specifically, we acknowledge that institutions take time to change but find that they may be moderated by more flexible, controllable factors. Because institutions are human-made constraints on our behaviours, we suggest that human capital may play a role. The empirical tests on a set of Vietnamese SMEs confirm that both types of built-up and imported human capital play a role in moderating (strengthening) the impacts of local governance on firm performance.

This study offers a set of recommendations for governments concerned with facilitating small businesses. First, more resources should be allocated to local governments to improve their capabilities in executing regulations. While improving national legal institutions is important in the long-run, small businesses are more responsive to their surrounding governance arrangements. Second, local governments should encourage multiculturalism. By welcoming migrants from elsewhere, a region could facilitate the skills and knowledge interactions (spill-overs) between migrants and life-long residents, resulting in more innovation, a less risk-averse attitude, and a greater tolerance of diversity, which are the antecedents of productivity and economic growth 
(Cheong et al., 2007). Third, by improving local education, authorities can strengthen the positive influence of local governance on firm performance (Nguyen et al., 2018). This strategy is particularly plausible in regions with sticky norms (e.g., corruption), which they cannot get rid of in the shortterm.

This study is not without limitations that should be acknowledged but which also provide potential avenues for future research. First, local institutional settings are multi-dimensional, including both the formal and informal arrangements. We use local government quality as a proxy for institutional settings but note that this is far from being able to fully reflect the entirety of the local institutions. Future research may employ a better proxy to measure local institutions. Moreover, the dataset employed in this study is country-specific. One of the main weaknesses of a country-specific research design is that we only observe within-country migration effects, i.e., in-migration. In-migrants, however, share similar institutional and cultural backgrounds to the life-long residents, which may diminish the (potential) negative effects of migration on local institutions that were seen in Borjas's cross-country immigration analysis (Borjas, 2014). Future research should therefore re-test the validity of our findings using a multi-country dataset with longer survey periods. Also, due to data limitations, we are unable to distinguish the effects of high-skilled in-migration from low-skilled inmigration. It is interesting and policymaking-relevant to examine the relative importance of the two types of migration on local firm performance. Future studies should address this issue by examining whether or not the positive effects come mostly from high-skilled immigrants, as suggested by the literature.

To sum up, this study examines the impacts of local governance, local education and in-migration on small business performance. Given that national institutions are important to small business performance, but higher levels of institutions are sticky and take time to improve (Williamson, 2000), we suggest that policymakers should pay more attention to local governance quality instead of concentrating solely on the very broad general constitutional configurations. More importantly, they could also enhance local education and welcome migrants to strengthen the positive impacts of local governance on firm performance. 
Tables and Figures:

Table 1: Variable Definition and Summary Statistics

\begin{tabular}{|c|c|c|c|c|c|}
\hline Variable & Definition & Mean & SD & Min & Max \\
\hline Revenue growth & $\begin{array}{l}\text { The percentage change of revenue of a firm between two } \\
\text { consecutive years, using } 2010 \text { price level }\end{array}$ & 0.04 & 1.35 & -4.68 & 4.74 \\
\hline Profit growth & $\begin{array}{l}\text { The percentage change of profitability of a firm between } \\
\text { two consecutive years, using } 2010 \text { price level }\end{array}$ & 0.09 & 1.59 & -4.48 & 4.62 \\
\hline Local governance quality & $\begin{array}{l}\text { The PCI score, ranging from } 0 \text { to } 100 \text {, the higher the score, } \\
\text { the better the governance quality of local governments }\end{array}$ & 60.02 & 4.78 & 36.39 & 77.20 \\
\hline High-graduates & $\begin{array}{l}\text { The ratio of the number of high school graduates over the } \\
\text { provincial population }\end{array}$ & 94.63 & 9.13 & 38.57 & 99.98 \\
\hline In-migrants & $\begin{array}{l}\text { The ratio of the number of in-migrants over the provincial } \\
\text { population }\end{array}$ & 0.005 & 0.10 & -0.03 & 0.08 \\
\hline Firm age & Years of operation since the establishment & 5.72 & 4.57 & 1 & 68 \\
\hline Firm size & $\begin{array}{l}\text { Natural log of the number of employees in a firm (reported } \\
\text { here the number of employees) }\end{array}$ & 19.31 & 130 & 1 & 85,260 \\
\hline Owner age & Age of the owner of a business & 42.95 & 9.92 & 25 & 69 \\
\hline Owner gender & $\begin{array}{l}\text { A dummy variable, taking value } 1 \text { for male and value } 0 \text { for } \\
\text { female }\end{array}$ & 0.71 & 0.45 & 0 & 1 \\
\hline Owner education & $\begin{array}{l}\text { A category variable, taking value } 1 \text { for doctoral level, } 2 \text { for } \\
\text { masters, } 3 \text { bachelors, } 4 \text { college degrees, } 5 \text { professional } \\
\text { vocational degrees, } 6 \text { senior technical degrees, } 7 \text { junior } \\
\text { technical degrees, and } 8 \text { no degree }\end{array}$ & 5.51 & 1.70 & 1 & 8 \\
\hline Population density & $\begin{array}{l}\text { The ratio of population over area by province per year, in } \\
\text { persons per } \mathrm{km}^{2}\end{array}$ & 2,021 & 1,376 & 40 & 4,025 \\
\hline Consumption power & $\begin{array}{l}\text { The value of average consumption of a province in a year } \\
\text { depreciated to } 2010 \text { value, in million VND per-capita }\end{array}$ & 54.89 & 72.45 & 0.41 & 89.12 \\
\hline Workforce & $\begin{array}{l}\text { The ratio of the number of working population to total } \\
\text { population }\end{array}$ & 0.63 & 0.33 & 0.29 & 0.84 \\
\hline FDI per-capita & $\begin{array}{l}\text { The ratio of the foreign direct investment value to the total } \\
\text { population, in million VND per-capita }\end{array}$ & 3.85 & 3.66 & 0.00 & 27.92 \\
\hline
\end{tabular}

Note: The number of observations is 1,366,533 firm-year in Vietnam in the period 2006-2016. The sample includes domestic private businesses. The governance quality variable is obtained from the Provincial Competitiveness Index (PCI) dataset. The firm-level variables are obtained from the Annual Enterprise Survey dataset of Vietnam General Statistics Office (GSO). The provincial-level variables are obtained from the Annual Statistics Books of Vietnam. 
Table 2: Regression Results

\begin{tabular}{|c|c|c|c|c|c|c|}
\hline \multirow{4}{*}{ Local governance quality } & (1) & (2) & (3) & (4) & (5) & (6) \\
\hline & $\begin{array}{l}\text { Revenue } \\
\text { growth }\end{array}$ & $\begin{array}{l}\text { Revenue } \\
\text { growth }\end{array}$ & $\begin{array}{l}\text { Revenue } \\
\text { growth }\end{array}$ & $\begin{array}{l}\text { Profit } \\
\text { growth }\end{array}$ & $\begin{array}{l}\text { Profit } \\
\text { growth }\end{array}$ & $\begin{array}{l}\text { Profit } \\
\text { growth }\end{array}$ \\
\hline & $4.146^{* * *}$ & $3.081 * *$ & $0.878^{* *}$ & $4.624^{* *}$ & $3.782^{*}$ & $1.385^{* *}$ \\
\hline & $(1.016)$ & $(1.386)$ & $(0.383)$ & $(2.126)$ & $(2.067)$ & $(0.657)$ \\
\hline \multirow[t]{2}{*}{ In-migrants } & $1.627^{* *}$ & $0.579 * * *$ & $0.402^{*}$ & $1.529 * *$ & $3.155^{* * *}$ & $1.163^{* * *}$ \\
\hline & $(0.687)$ & $(0.205)$ & $(0.224)$ & $(0.748)$ & $(0.696)$ & $(0.368)$ \\
\hline \multirow[t]{2}{*}{ High-graduates } & $0.481^{* *}$ & $1.042^{* * *}$ & $2.940^{* * *}$ & 1.142 & $1.151^{* *}$ & $2.590^{*}$ \\
\hline & $(0.239)$ & $(0.256)$ & $(0.812)$ & $(0.790)$ & $(0.533)$ & $(1.516)$ \\
\hline \multirow[t]{2}{*}{ In-migrants $\times$ Governance } & & & $0.067^{* * *}$ & & & $0.117^{* * *}$ \\
\hline & & & $(0.016)$ & & & $(0.037)$ \\
\hline \multirow[t]{2}{*}{ High-graduates $\times$ Governance } & & $0.136^{* * *}$ & & & 0.003 & \\
\hline & & $(0.026)$ & & & $(0.004)$ & \\
\hline \multirow[t]{2}{*}{ Firm age } & $-3.493^{* * *}$ & $-0.858^{* * *}$ & 0.221 & 0.274 & $0.460^{*}$ & 0.210 \\
\hline & $(0.205)$ & $(0.098)$ & $(0.267)$ & $(0.232)$ & $(0.255)$ & $(0.248)$ \\
\hline \multirow[t]{2}{*}{ Firm age squared } & $0.075^{* * *}$ & $0.019^{* * *}$ & -0.005 & -0.002 & -0.005 & -0.003 \\
\hline & $(0.005)$ & $(0.002)$ & $(0.006)$ & $(0.004)$ & $(0.005)$ & $(0.005)$ \\
\hline \multirow[t]{2}{*}{ Firm size } & $-2.950 * * *$ & $-3.847^{* * *}$ & -0.170 & 0.005 & 0.098 & $1.268^{* *}$ \\
\hline & $(0.478)$ & $(1.126)$ & (1.799) & $(0.803)$ & $(0.882)$ & $(0.576)$ \\
\hline \multirow[t]{2}{*}{ Owner age } & $-0.113^{* *}$ & $-0.144^{* * *}$ & $-0.112^{* * *}$ & $-0.150^{* * *}$ & $-0.143^{* *}$ & $-0.158^{* * *}$ \\
\hline & $(0.048)$ & $(0.025)$ & $(0.026)$ & $(0.042)$ & $(0.071)$ & $(0.041)$ \\
\hline \multirow[t]{2}{*}{ Owner gender } & $-0.858^{* *}$ & $-1.336^{* *}$ & $-1.915^{* * *}$ & -1.755 & -1.662 & $-3.509 * * *$ \\
\hline & $(0.352)$ & $(0.524)$ & $(0.632)$ & $(1.400)$ & $(1.594)$ & $(1.118)$ \\
\hline \multirow[t]{2}{*}{ Population density } & $-0.023^{* *}$ & -0.003 & $-0.012^{* * *}$ & 0.004 & 0.006 & 0.002 \\
\hline & $(0.009)$ & $(0.004)$ & $(0.003)$ & $(0.005)$ & $(0.008)$ & $(0.005)$ \\
\hline \multirow[t]{2}{*}{ Consumption power } & -1.127 & -0.213 & 0.389 & -0.730 & -1.028 & -0.548 \\
\hline & $(0.686)$ & $(0.532)$ & $(0.388)$ & $(0.705)$ & $(1.139)$ & $(0.563)$ \\
\hline \multirow[t]{2}{*}{ Workforce } & $244.974^{* * *}$ & $113.193^{* *}$ & $113.883^{* *}$ & 90.574 & 131.521 & 81.541 \\
\hline & $(90.583)$ & $(47.763)$ & $(55.321)$ & $(80.183)$ & $(114.012)$ & $(66.075)$ \\
\hline \multirow[t]{2}{*}{ FDI per-capita } & 1.719 & 0.707 & 0.773 & -1.223 & -0.912 & -0.396 \\
\hline & $(1.356)$ & $(0.452)$ & $(0.717)$ & $(1.030)$ & $(1.021)$ & $(0.520)$ \\
\hline Observations & $1,366,533$ & $1,366,533$ & $1,366,533$ & $1,366,533$ & $1,366,533$ & $1,366,533$ \\
\hline VIF & 2.34 & 3.67 & 3.48 & 2.54 & 4.23 & 3.95 \\
\hline Hansen (J) p_value & 0.16 & 0.57 & 0.09 & 0.78 & 0.75 & 0.11 \\
\hline SW first-stage F-test p_value & 0.00 & 0.00 & 0.00 & 0.00 & 0.00 & 0.00 \\
\hline R-squared & 0.11 & 0.07 & 0.10 & 0.15 & 0.20 & 0.12 \\
\hline
\end{tabular}

Note: The independent variable in columns (1) to (3) is revenue growth; the independent variable in columns (4) to (6) is profit growth. All estimations include full sets of two-digit industry dummies, 11-year dummies, 63 provincial dummies, and 8 dummies for owner education. Standard errors are clustered to the provincial level, and test statistics are asymptotically robust to heteroskedasticity. The estimator is two-step IV-GMM. The endogenous variable is local governance quality. The instrumental variables employed are Period in office, the number of months (average for a given year) that the top provincial leader is in his/her position; Leader switch, a dummy that takes value 1 if there is a change of provincial leader in a year, and 0 otherwise; Third-year, a dummy that takes value 1 if a leader is in the third year of tenure, and 0 otherwise; Fifth-year, a dummy that takes value 1 if a leader is in the fifth year of tenure, and 0 otherwise. The variable firm size is lagged one period. Hansen (J) is overidentification test, under the null that the overidentifying restrictions are valid, the statistic is asymptotically distributed as a chi-square variable. VIF is a test of multicollinearity. Sanderson-Windmeijer (SW) first-stage chi-squared and F statistics are tests of under-identification and weak identification, respectively, of individual endogenous regressors, under the null that the particular endogenous regressors in question are unidentified. * indicates significant at $10 \%,{ }^{* *}$ indicates significant at $5 \%$, and *** indicates significant at $1 \%$. 


\section{Figure 1: Theoretical Framework}

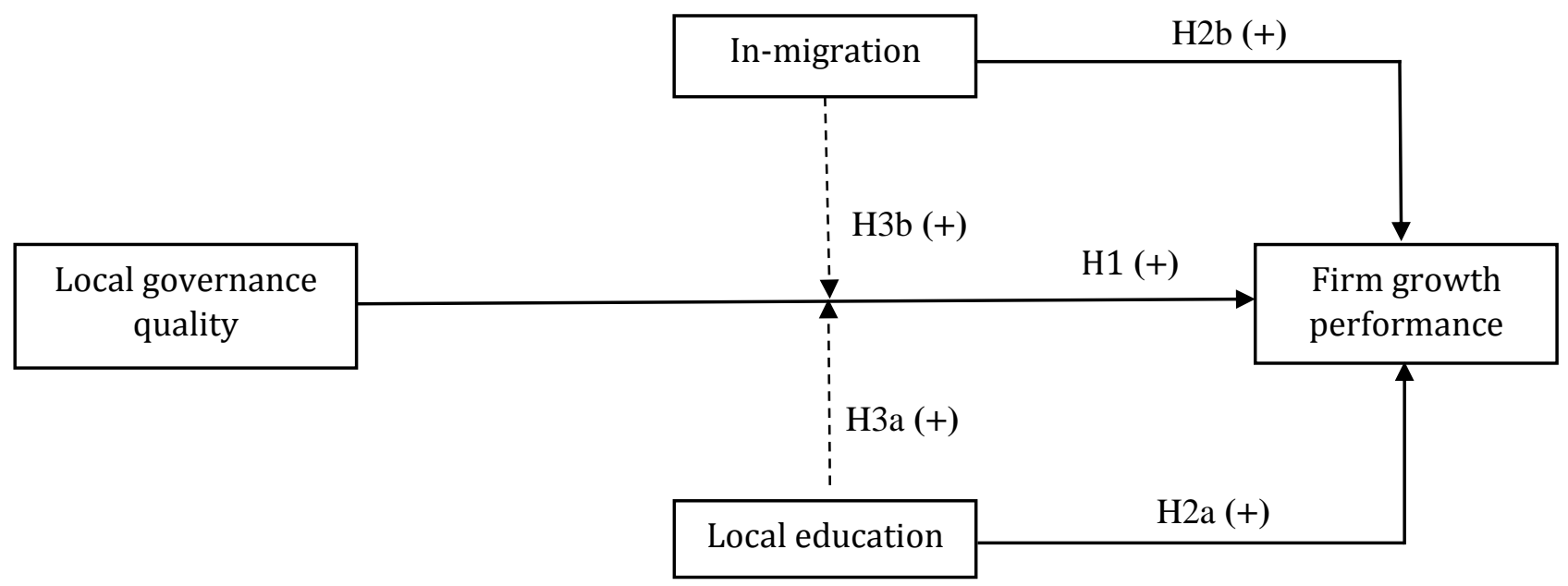

Note: This figure illustrates the expected relationship between local governance, in-migration, education, and firm growth performance. The solid arrows represent the direct effects between two constructs. The dash arrows represent the moderation effects of a construct on the relationship of two other constructs. Hypothesis H1 proposes a positive relationship between local governance quality and firm growth performance. Hypothesis $\mathrm{H} 2 \mathrm{a}$ and $\mathrm{H} 2 \mathrm{~b}$ propose a positive relationship between local education/in-migration and firm growth performance. Hypothesis $\mathrm{H} 3 \mathrm{a}$ and $\mathrm{H} 3 \mathrm{~b}$ propose positive moderation effects of local education/inmigration on the relationship between local governance quality and firm growth performance.

Figure 2: Predictive Margins
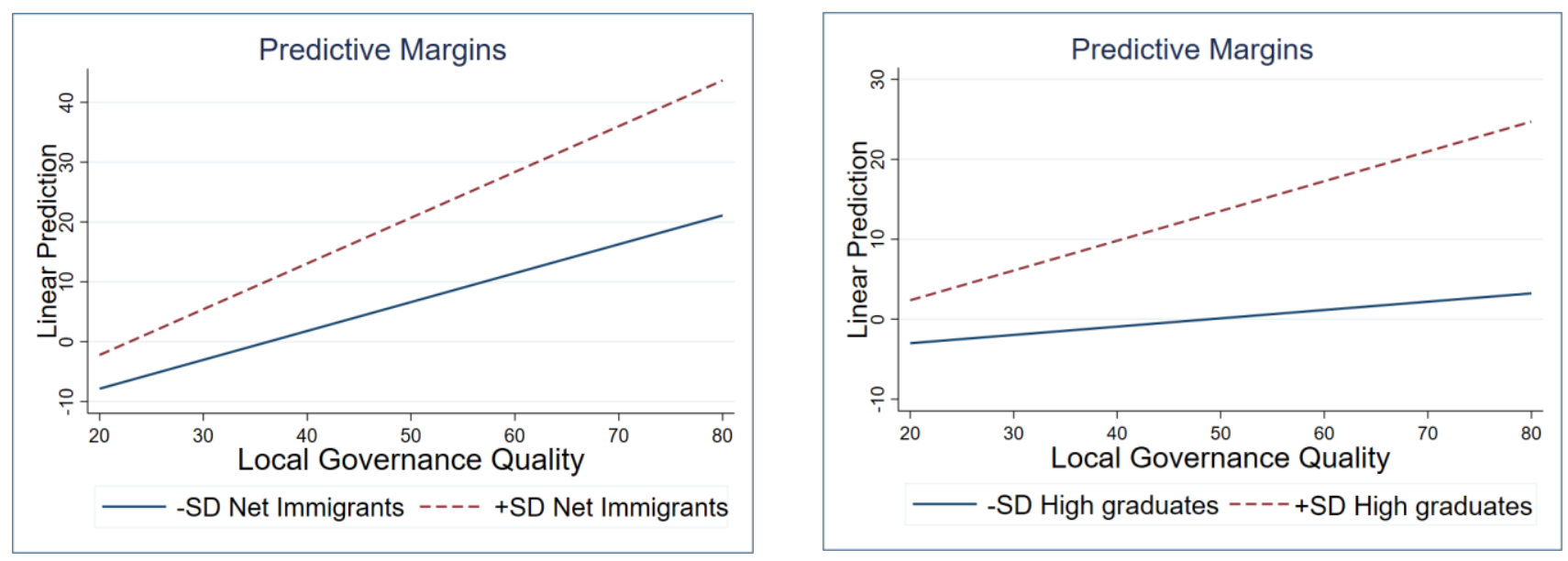

Note: This figure illustrates the predictive margins of revenue growth by different numbers of in-migrants (the left figure) and high-graduates (the right figure). The solid lines indicate the predictive margins of revenue growth given in-migrants and high-graduates are one standard deviation (SD) below their means. Meanwhile, the dash lines indicate the predictive margins of revenue growth given in-migrants and high-graduates are one standard deviation (SD) above their means 


\section{References:}

Acemoglu, D., \& Johnson, S. (2005). Unbundling Institutions. Journal of Political Economy, 113(5), 949995.

Ahlstrom, D., \& Bruton, G. D. (2010). Rapid institutional shifts and the co-evolution of entrepreneurial firms in transition economies. Entrepreneurship: Theory and Practice, 34(3), 531-554.

Aidis, R. (2005). Institutional Barriers to Small- and Medium-Sized Enterprise Operations in Transition Countries. Small Business Economics, 25(4), 305-318.

Altonji, J. G., Elder, T. E., \& Taber, C. R. (2005). An Evaluation of Instrumental Variable Strategies for Estimating the Effects of Catholic Schooling. The Journal of Human Resources, 40(4), 791-821.

Armen, H., \& Quinton, M. (2012). Institutional Trust, Education, and Corruption: A Micro-Macro Interactive Approach. The Journal of Politics, 74(3), 739-750.

Autio, E., \& Fu, K. (2015). Economic and political institutions and entry into formal and informal entrepreneurship. Asia Pacific Journal of Management, 32(1), 67-94.

Baudassé, T., Bazillier, R., \& Issifou, I. (2018). Migration and Institutions: Exit and Voice (from abroad)? Journal of Economic Surveys, 32(3), 727-766.

Bellows, J., \& Miguel, E. (2009). War and local collective action in Sierra Leone. Journal of Public Economics, 93(11), 1144-1157.

Bolen, J. B., \& Williamson, C. R. (2019). The Path of Reform: The Consequences of Institutional Volatility. Kyklos, 72(3), 400-425.

Borjas, G. J. (2014). Immigration economics. Cambridge, Mass.: Harvard University Press.

Bruton, G. D., Ahlstrom, D., \& Li, H. L. (2010). Institutional theory and entrepreneurship: Where are we now and where do we need to move in the future? Entrepreneurship: Theory and Practice, 34(3), 421-440.

Carbonara, E., Santarelli, E., \& Tran, H. (2016). De jure determinants of new firm formation: how the pillars of constitutions influence entrepreneurship. Small Business Economics, 47(1), 139-162.

Card, D., \& Peri, G. (2016). Immigration Economics by George J. Borjas: A Review Essay. Journal of Economic Literature, 54(4), 1333-1349.

Carpenter, R. E., \& Petersen, B. C. (2002). Is The Growth of Small Firms Constrained by Internal Finance? Review of Economics \& Statistics, 84(2), 298-309.

Charron, N., Dijkstra, L., \& Lapuente, V. (2014). Regional Governance Matters: Quality of Government within European Union Member States. Regional Studies, 48(1), 68-90.

Cheong, P., Edwards, R., Goulbourne, H., \& Solomos, J. (2007). Immigration, social cohesion and social capital: A critical review. Critical Social Policy, 27(1), 24-49.

Clark, J. R., Lawson, R., Nowrasteh, A., Powell, B., \& Murphy, R. (2015). Does Immigration Impact Institutions? Public Choice, 163(3-4), 321-335.

Clemens, M. A., \& Pritchett, L. (2016). The new economic case for migration restrictions an assessment. Retrieved from http://hdl.handle.net/10419/141489

Collier, P. (2015). Exodus : how migration is changing our world. New York: Oxford University Press.

Cull, R., \& Xu, L. C. (2005). Institutions, Ownership, and Finance: The Determinants of Profit Reinvestment among Chinese Firms. Journal of Financial Economics, 77(1), 117-146.

Dana, L. P. (1994). A Marxist Mini-Dragon? Entrepreneurship in Today's Vietnam. Journal of Small Business Mangement, 32(2), 95-102. 
De Jong, G., Tu, P. A., \& Van Ees, H. (2012). Which Entrepreneurs Bribe and What Do They Get From It? Exploratory Evidence From Vietnam. Entrepreneurship: Theory and Practice, 36(2), 323345.

Dheer, R. J. S. (2017). Cross-National Differences in Entrepreneurial Activity: Role of Culture and Institutional Factors. Small Business Economics, 48(4), 813-842.

Diewert, W. E., \& Nakamura, A. O. (2007). Chapter 66 The Measurement of Productivity for Nations. In J. H. James \& E. L. Edward (Eds.), Handbook of econometrics (Vol. Volume 6, Part A, pp. 4501-4586): Elsevier.

DiMaggio, P. J., \& Powell, W. W. (1991). The new institutionalism in organizational analysis. London: University of Chicago Press.

Du, J., \& Mickiewicz, T. (2016). Subsidies, rent seeking and performance: Being young, small or private in China. Journal of business venturing, 31(1), 22-38.

Efendic, A., Mickiewicz, T., \& Rebmann, A. (2015). Growth aspirations and social capital: Young firms in a post-conflict environment. International Small Business Journal, 33(5), 537-561.

Eicher, T., García-Peñalosa, C., \& van, Y., Tanguy. (2009). Education, Corruption, and the Distribution of Income. Journal of Economic Growth, 14(3), 205-231.

Fritsch, M., \& Wyrwich, M. (2014). The long persistence of regional levels of entrepreneurship: Germany, 1925-2005. Regional Studies(6), 955-973.

Gjalt, d. J., Tu, P. A., \& Hans, v. E. (2012). Which Entrepreneurs Bribe and What Do They Get From It? Exploratory Evidence From Vietnam. Entrepreneurship: Theory \& Practice, 36(2), 323-345.

Guariglia, A. (2008). Internal financial constraints, external financial constraints, and investment choice: Evidence from a panel of UK firms. Journal of Banking and Finance, 32(9), 1795-1809.

Hakhverdian, A., \& Mayne, Q. (2012). Institutional Trust, Education, and Corruption: A Micro-Macro Interactive Approach. The Journal of Politics, 74(3), 739.

Hirschman, A. O. (2007). Exit, voice, and loyalty: responses to decline in firms, organizations, and states. Cambridge, Mass.: Harvard Univ. Press.

Iversen, J., Malchow-Moller, N., \& Sorensen, A. (2016). Success in Entrepreneurship: A Complementarity between Schooling and Wage-Work Experience. Small Business Economics, 47(2), 437-460.

James, B. E., \& McGuire, J. B. (2016). Transactional-institutional fit: Corporate governance of R\&D investment in different institutional contexts. Journal of Business Research, 69(9), 3478-3486.

Jensen, P. H. (2014). Understanding the Impact of Migration on Innovation. Australian Economic Review, 47(2), 240-250.

Jetter, M., \& Parmeter, C. F. (2018). Sorting through global corruption determinants: Institutions and education matter - Not culture. World Development, 109(2018), 279-294.

Kolstad, I., \& Wiig, A. (2015). Education and Entrepreneurial Success. Small Business Economics, 44(4), 783-796.

La Porta, R., Florencio, L.-d.-S., Shleifer, A., \& Vishny, R. (1999). The Quality of Government. Journal of Law, Economics, \& Organization, 15(1), 222-248.

Lamine, W., Jack, S., Fayolle, A., \& Chabaud, D. (2015). One Step Beyond? Towards a Process View of Social Networks in Entrepreneurship: Editorial. Entrepreneurship and Regional Development, 27(7-8), 413-429.

Le, A. T. (1999). Empirical Studies of Self-Employment. Journal of Economic Surveys, 13(4), 381-416. 
Levie, J. (2007). Immigration, In-Migration, Ethnicity and Entrepreneurship in the United Kingdom. Small Business Economics, 28(2-3), 143-169.

Light, I. (1979). Disadvantaged Minorities in Self-Employment. Comparative Sociology, 20(1), 31-45.

Lucas, R. E. (1978). On the Size Distribution of Business Firms. Bell Journal of Economics, 9(2), 508523.

Malesky, E., McCulloch, N., \& Nhat, N. D. (2015). The impact of governance and transparency on firm investment in Vietnam. Economics of Transition, 23(4), 677-715.

Matlay, H., \& Piperopoulos, P. (2012). Could Higher Education Programmes, Culture and Structure Stifle the Entrepreneurial Intentions of Students? Journal of Small Business and Enterprise Development, 19(3), 461-483.

Millán, J. M., Congregado, E., Román, C., van Praag, M., \& van Stel, A. (2014). The value of an educated population for an individual's entrepreneurship success. Journal of business venturing, 29(5), 612-632.

Nguyen, \& Dijk, v. (2012). Corruption, Growth, and Governance: Private vs. State-Owned Firms in Vietnam. Journal of Banking and Finance, 36(11), 2935-2948.

Nguyen, B. (2018). Entrepreneurial Reinvestment: Local Governance, Ownership, and Financing Matter - Evidence from Vietnam. Journal of Small Business Management, In press.

Nguyen, B. (2019). Local Institutions on Small Firm Investments: Degrees of Institutional Persistence Matter. International Journal of Entrepreneurship and Small Business, In Press.

Nguyen, B., Mickiewicz, T., \& Du, J. (2018). Local governance and business performance in Vietnam: the transaction costs perspective. Regional Studies, 52(4), 542-557.

Nguyen, D. T. N., Teo, S. T. T., \& Ho, M. (2018). Development of human resource management in Vietnam: A semantic analysis. Asia Pacific Journal of Management, 35(1), 241.

Nguyen, Q. A., Mort, G. S., \& D'Souza, C. (2015). Vietnam in Transition: SMEs and the Necessitating Environment for Entrepreneurship Development. Entrepreneurship and Regional Development, 27(3-4), 154-180.

North, D. C. (1990). Institutions, institutional change and economic performance Cambridge : Cambridge University Press.

Oster, E. (2019). Unobservable Selection and Coefficient Stability: Theory and Evidence. Journal of Business \& Economic Statistics, 37(2), 187-204.

Padilla, A., \& Cachanosky, N. (2018). The Grecian horse: does immigration lead to the deterioration of American institutions? Public Choice, 174(3/4), 351-405.

Peng, M. W. (2002). Towards an Institution-Based View of Business Strategy. Asia Pacific Journal of Management, 19(2/3), 251-267.

Peroni, C., Riillo, C. A. F., \& Sarracino, F. (2016). Entrepreneurship and Immigration: Evidence from GEM Luxembourg. Small Business Economics, 46(4), 639-656.

Poprawe, M. (2015). On the relationship between corruption and migration: empirical evidence from a gravity model of migration. Public Choice, 163(3/4), 337-354.

Powell, B., Clark, J. R., \& Nowrasteh, A. (2017). Does mass immigration destroy institutions? 1990s Israel as a natural experiment. Journal of Economic Behavior \& Organization, 141(9), 83-95.

Robinson, P. B., \& Sexton, E. A. (1994). The effect of education and experience on self-employment success. Journal of business venturing, 9(2), 141-156. 
Sequeira, S., Nunn, N., \& Qian, N. (2017). Migrants and the making of America : the short and long run effects of immigration during the Age of Mass Migration. Retrieved from http://www.cepr.org/active/publications/discussion papers/dp.php?dpno=11899

Soriano, D. R., \& Castrogiovanni, G. J. (2012). The Impact of Education, Experience and Inner Circle Advisors on SME Performance: Insights from a Study of Public Development Centers. Small Business Economics, 38(3), 333-349.

Stephan, U., Uhlaner, L. M., \& Stride, C. (2015). Institutions and social entrepreneurship: the role of institutional voids, institutional support, and institutional configurations. Journal of International Business Studies, 46(3), 308-331.

Tonoyan, V., Strohmeyer, R., Habib, M., \& Perlitz, M. (2010). Corruption and entrepreneurship: How formal and informal institutions shape small firm behavior in transition and mature market economies. Entrepreneurship: Theory and Practice, 34(5), 803-831.

Tran, H. T. (2018). Institutional quality and market selection in the transition to market economy. Journal of business venturing, Artile in press.

Tran, H. T., \& Santarelli, E. (2014). Capital Constraints and the Performance of Entrepreneurial Firms in Vietnam. Industrial and Corporate Change, 23(3), 827-864.

Valliere, D., \& Peterson, R. (2009). Entrepreneurship and Economic Growth: Evidence from Emerging and Developed Countries. Entrepreneurship and Regional Development, 21(5-6), 459-480.

Van Der Sluis, J., Van Praag, M., \& Vijverberg, W. (2008). Education and Entrepreneurship Selection and Performance: A Review of the Empirical Literature. Journal of Economic Surveys, 22(5), 795-841.

Van Praag, M., \& Van Stel, A. (2013). The More Business Owners, the Merrier? The Role of Tertiary Education. Small Business Economics, 41(2), 335-357.

Van Praag, M., van Witteloostuijn, A., \& van der Sluis, J. (2013). The Higher Returns to Formal Education for Entrepreneurs versus Employees. Small Business Economics, 40(2), 375-396.

Venard, B. (1998). Vietnam in mutation: Will it be the next tiger or a future jaguar? Asia Pacific Journal of Management, 15(1), 77-100.

Wennberg, K., Pathak, S., \& Autio, E. (2013). How Culture Moulds the Effects of Self-Efficacy and Fear of Failure on Entrepreneurship. Entrepreneurship and Regional Development, 25(9-10), 756780.

Williamson, O. E. (2000). The New Institutional Economics: Taking Stock, Looking Ahead. Journal of Economic Literature, 38(3), 595-613.

Zelekha, Y. (2013). The Effect of Immigration on Entrepreneurship. Kyklos, 66(3), 438-465.

Zhou, W. (2014). Regional institutional development, political connections, and entrepreneurial performance in China's transition economy. Small Business Economics, 43(1), 161-181.

Zhou, W. (2017). Institutional environment, public-private hybrid forms, and entrepreneurial reinvestment in a transition economy. Journal of business venturing, 32(2), 197-214. 